\title{
MEMORY
}

\section{OF THE WARSAW PACT INTERVENTION IN THE POST-AUGUST HISTORY 1968-1989}

\author{
Manipulation, Oblivion, and Conservation
}

In the spring and summer of 1968, a process accelerating the previous step-by-step easing of the political regime picked up unpredecented force in Czechoslovakia.' It took along a major part of society, which pinned its hopes for a better life on support of the new Communist leadership. Alexandr Dubček, who succeeded Antonín Novotný as the leader of the Communist Party in January 1968, became one of the principal faces of the so-called Prague Spring. Although the new party leadership did not offer, apart from the abolition of censorship, any fundamental structural changes of the political regime, it nevertheless gave people a chance to hope that a number of changes were and would be possible. Such faith was also fueled by a newfound freedom of speech, which permitted public discussion of matters which people had previously only whispered about, or even preferred not to talk about at all. Civic society started waking up; associations and organizations previously banned by Communists were re-established, or new ones founded (Hoppe 2009). Although none of these entities officially questioned the principle of the leading role of the Communist Party, the spontaneous movement in the society made the political center uneasy, the more so that Czechoslovakia's allies in the Warsaw Pact led by the Soviet Union

1. The article is a product of the "Czech society and the Soviet Army 1968-1991" project sponsored by the Grant Agency of the Czech Republic under Project No. 17-06744S.
Marie Cerná

Institute

of Contemporary History

Czech Academy of Sciences Prague, Czech Republic

(D) 
made their dissatisfaction with the developments in the country threateningly plain. Efforts by the reform Communists to slow down the democratization process and thus prove their loyalty to the other allied countries failed. On August 21st, 1968 troops from the Soviet Union, Hungary, Poland, and Bulgaria poured into Czechoslovakia and Soviet politicians justified it as an internationalist duty and a friendly assistance. According to them, the Prague Spring encouraged counter-revolutionary and reactionary forces, who, backed by international imperialists, hurled the country into chaos and tried to dismantle the socialist system. On the other hand, citizens of Czechoslovakia, who were flooding the streets as tanks were invading the country during the night and in the morning of August 21st were shocked and did not hesitate to flatly call it an occupation. As for the top party leaders, the situation was more complicated as some of them plotted with Soviets against Dubček and other reformists. Nevertheless the Presidium gathered on the night of the invasion voted 7 to 4 to adopt a statement condemning the invasion as a violation of "all principles governing relations between socialist states" and a "breach of international law" (Vondrová, Navrátil 2000: 454). The statement was followed by thousands of declarations made by state institutions, enterprises, schools, mass organizations and local political bodies condemning the Warsaw Pact invasion, often referring to it as an occupation. For a brief moment, the occupation became

1968 Transnational Legacies a reality shared by the majority and confirmed by the political representation. Those who welcomed the allied forces were discredited as traitors and collaborators. This situation was obviously unacceptable for the Soviets and their Czechoslovak supporters. It was a matter of high political interest to enforce an interpretation of the August invasion as 'fraternal assistance,' and, in fact, also one of the crucial issues of the normalization process.

My work presents a brief history of transformations of the official picture of the August invasion, the final acceptance of the Soviet version in 1969, and its confirmation a year later. I have examined its further developments until the fall of the Communist regime in 1989, or, in other words, a step-by-step tendency to erase the year 
1968, including the August invasion, from the official interpretation rather than present it as an important milestone of Communist history. I also monitor the fate of the memory of the August 1968 occupation that was banned from the public sphere.

\section{FROM AN OCCUPATION TO FRIENDLY ASSISTANCE}

Immediately following the invasion, Czechoslovak leaders were forced to sign the so-called Moscow Protocol (Navrátil 1998: 477). One of its consequences was a reintroduction of censorship that first of all prohibited the use of the word 'occupation' or 'occupier' in connection with Soviets and Warsaw Pact armies (Hoppe 2004: 16-17). In October 1968, a Treaty on the Temporary Presence of Soviet Forces in Czechoslovakia was signed (Navrátil 1998: 533-36). Under the terms of the treaty, most of the Warsaw Pact troops were withdrawn from Czechoslovakia, but, on the other hand, the presence of Soviet troops for an undefined period of time was made legal; a secret amendment to the treaty mentions 75,000 Soviet soldiers. Both the Moscow Protocol and the Temporary Presence Treaty dealt mainly with practical aspects, basically circumventing the issue of the political nature of the invasion. Dubček thus had some room to maneuver, which permitted him to state that there were differences between the Czechoslovak and Soviet parties in the "evaluation of the internal political situation." As the past was burdened by a mutual "misunderstanding," he recommended focusing on the future (Vondrová, Navrátil 2001: 213-215). Dubček's leadership dismissed the concept of occupation, and was prepared to condemn and suppress any open protest against the presence of the Soviet Army since autumn 1968. However, it neither withdrew the official statement of the Central Committee of the Communist Party of Czechoslovakia about the unlawful nature of the military intervention, nor accepted the Soviet concept of 'friendly assistance' to protect the country against counterrevolution. The half-baked solution naturally was not enough for Brezhnev, and he and his fellow leaders continued to push their Czechoslovak counterparts toward a reassessment of the Prague Spring and August invasion. According to Brezhnev, it was "necessary that the Central Committee and the government clearly state that the arrival of the allied armies was an inevitable 
measure prompted by activities of anti-socialist elements" (Vondrová, Navrátil 1997: 41).

In April 1969, Gustáv Husák succeeded Dubček as the party leader due to the pressure of Soviet politicians and their Czechoslovak supporters. The new party leadership showed much more willingness to re-evaluate the year 1968, including the August 21 invasion. As early as April, it established a commission tasked to perform an analysis of political development both prior to and during the year 1968. And, to show obedience, the first official delegation of government and party representatives led by President Ludvík Svoboda paid a visit to the Soviet Army Headquarters in Milovice in May 1969. However, top-ranking political leaders took their time with the analysis of the political situation. Partly influenced by changes at the top, partly under the pressure of the Soviet allies, first personal purges at the district and regional levels of the party took place in the spring and summer of 1969 As a result, many local political organizations repealed the August 1968 statement condemning the military invasion, which Soviet politicians did not forget to commend. They nevertheless kept pointing out the necessity to "resolve this issue at the central level" (Vondrová 2011: 468-470). The desired change came in the autumn of 1969, soon after the Czechoslovak leadership had ordered its own armed forces to brutally suppress protests and riots on the occasion of the first anniversary of the inva-

1968 Transnational Legacies sion. At a plenary session held in September 1969, the Central Committee of the Communist Party of Czechoslovakia recanted the August 1968 statement condemning the invasion, replacing it by another statement to the effect that "the entry of allied troops [...] was in the interest of the defence of socialism against rightwing, anti-socialist, and counterrevolutionary forces" (Vondrová, Navrátil 2003: 599). Vettings and purges at every level followed; first of party officials, in 1970 of all party members, and finally of non-party citizens. The purpose of the vettings was, inter alia, to 'teach' people the official version of the story, to make them declare their dissociation from liberalization processes of the Prague Spring, and to accept the necessity of the Soviet invasion. (Černá 2012: 199-233) Millions of people had first-hand experience of, 
and were threatened by a variety of sanctions in connections with, the limits of what one could publicly say about the year 1968.

\section{A LESSON FROM THE CRISIS DEVELOPMENT}

While the year 1969 was still a year of political and public clashes between representatives of different opinions, with the boycott of pro-Soviet activities still prevailing, the year 1970 was a triumph of the Soviet version of events. On the second anniversary of August 21, opulent ceremonies took place all over the country to express thanks for the internationalist help rendered in 1968, accompanied by a campaign in normalized mass media. Newspapers published articles such as "August 21st, 1968-Plans of the Counterrevolution Thwarted" which wrote about "the assistance that prevented a disaster." In short, everything indicated that a new tradition was being born-one of the day of victory over the counterrevolution. The mass media highlighted the positive role of the Soviet Army, even at other times, bringing news about friendly relations between Soviet soldiers and the Czechoslovak society. Manifestations of friendly relations with Soviet soldiers became a part of the mandatory political loyalty with the regime. The heroic glorification of the military intervention in August 1968 was confirmed by an official document with a rather clumsy title, A Lesson from the Crisis Development in the Party and Society after the XIII Congress of the Communist Party of Czechoslovakia, which the Central Committee of the Communist Party of Czechoslovakia approved in December 1970. The ideological pamphlet, a collective work of top leaders of the party, presented the political developments of 1968 in an overly dramatic manner; the country was allegedly facing "fratricidal fight," and it was only the "international help" in August that prevented "bloodshed" (Slouka 1972: 68). Those who had been labelled quislings and traitors in 1968 were commended for their steadfast stance defending the principles of Marxism-Leninism and internationalism even under adverse conditions. The Lesson became an iconic text and a mandatory interpretation framework which the party leadership adhered to until its demise in 1989. It was published in many editions,

2. 21. srpen1968-konec plánů kontrarevoluce." Stráž lidu. August 20th, 1970. 
including a special version for secondary schools. Its preface explained to students that the booklet would convey to them "deep historical truth" about the "catastrophic situation" in 1968, when the country was on the verge of a "civil war" (Slouka 1972: 3-21). The memory of the occupation in August 1968 was relegated to the private sphere, or was maintained among exiles and dissidents, who regularly remembered the anniversary on August 21st.

\section{FRIENDSHIP FOREVER}

The fact that the Lesson from the Crisis Development remained unrevisited until 1989 does not mean that there was no development in the practical application of its principles. The massive political campaign in 1970 awakened the hopes of those who had welcomed the 1968 invasion. Their support of the Soviet policy and friendly relations with the Soviet Army were officially recognized; some of them were decorated, or at least symbolically rehabilitated. For many of them, the day of August 21st, 1968, became another milestone of the Communist struggle, the time when they mobilized themselves in defence of the socialist system and friendship with the Soviet Union. The fiftieth anniversary of the establishment of the Communist Party of Czechoslovakia in 1971 was an opportunity to include the 1968 events among important historical moments and to emphasize the merits of faithful 'internationalists' who, unlike most of their fellow countrymen, had not succumbed to enticements of revisionism

1968 Transnational Legacies and right-wing opportunism. In 1971, it even looked like the date of August 21 could be included in the Communist calendar. However, the development since 1971 followed a different path. The date of August 21, associated with the invasion of Warsaw Pact troops, was probably too sensitive ${ }^{3}$, and the political leadership therefore decided not to draw attention to it anymore. For a few years, the regime kept praising the Soviet Army and its 'fraternal help,' but at the same time avoided any publicizing of the anniversary. The 'internationalist assistance' of 1968 thus did not earn a per-

3. As illustrated by increased readiness of and attention paid to the anniversary of August 21 by the Secret Police every year, in spite of the fact that the number of protests or manifestations related to the anniversary of the August invasion between 1970 and 1988 was negligible. 
manent place in the calendar and, save for round anniversaries in 1978 or 1988 , it was strictly not commemorated on August 21st. The lack of anchoring ultimately resulted in the absence of a cult comparable to other significant and repeatedly commemorated historical events. Nevertheless, there were other dates in the calendar which were connected with the Soviet Union and the Soviet Army in one way or another. Actually, it was the Soviet Army Day in February, the Liberation Day in May, the Slovak National Uprising anniversary in August, the anniversary of the Great October Revolution in November, or the whole Month of Czechoslovak-Soviet Friendship at the turn of November and December which presented an opportunity to commemorate, apart from the traditional merits of the Soviet Union, the help provided by the Soviet Army in 1968. It was included in a broad and binding commitment of the Czechoslovak-Soviet friendship which was vehemently restored at multiple levels of social and political life under the old slogan "With the Soviet Union forever, and never otherwise." An article describing the celebrations of the 55th anniversary of the Great October Revolution summarized the moments in which the Soviet Union had been instrumental in the fate of Czechoslovakia:

In every village, in every factory, at every school, words proclaiming our love to our liberators were heard [...] In a large community of socialist nations, our Czechoslovak Socialist Republic too is following, side by side with the Soviet Union, the path of the Great October Revolution. [...] Under the leadership of the Communist Party of Czechoslovakia, our working people have achieved remarkable successes in building up the socialist system. [...] With the fraternal help of the Warsaw Pact countries, they thwarted the schemes of enemies of socialism in 1968 and 1969. ${ }^{4}$

'The fraternal help' of 1968 was included among the events which the Soviet Union had traditionally been revered forthe liberation of Czechoslovakia, or the socialist revolution that provided an example and assistance to other countries. It also further strengthened celebrations of these traditional events. The entire normalization regime was accompanied by meticulously

4. "Se Sovětským svazem za štastnou budoucnost našeho lidu." Naše slovo, November 15th, 1972. 
orchestrated rites of devotedness toward the Soviet Union, which masses of people were forced to take part in. Just like in the fifties, the Soviet Union had to be mandatorily admired as an indisputable example to follow. While a separate cult of the 'internationalist help' was not born, the 'internationalist help' undoubtedly renewed and strengthened the cult of friendship with the Soviet Union.

\section{A PRESENCE WITHOUT A BEGINNING}

In the friendship cult mentioned above, the Soviet troops stationed in Czechoslovakia and, step by step, also dependents of their officers, had their place as well. All news about them, their activities, or their contacts with the Czechoslovak society were invariably introduced by words such as friendship, friendly, or their Russian equivalent-druzhba. The latter term, connected with the promotion of international relations within the socialist bloc, became an important part of the normalization vocabulary. In its ambivalence, it referred to formalistic and ordered activities, but it also raised a claim to a deep emotional experience. As a rule, the druzhba was organized by an official organization, such as the Union of the Czechoslovak-Soviet Friendship or the Czechoslovak Union of Women, but its content was a mixture of the formal and the informal. The druzhba comprised both discussions and political lectures or collective official ceremonies, as well as collective excursions, balls, Czech cuisine demonstrations for Soviet women, or Christmas parties for children. Apart from the traditions linked

Transnational Legacies to major historical events, there were also new traditions being built-those of the Czechoslovak-Soviet friendship represented by Soviet soldiers and their families. "It is already a tradition that Czech and Soviet children meet in Trutnov at the end of December to celebrate the end of the year [...] together." ${ }^{\text {Th }}$ The emphasis on the creation of new traditions of mutual friendly relations changed the reference frame of writing and speaking about Soviet soldiers. Its focus on present, everyday matters, and women and children, made it possible to leave the past and its awkward issues behind. In newspaper articles, Soviet women and children

5. Nyserová, Libuše: "Setkání českých a sovětských dětí." Krkonošská pravda, January 20th, 1983. 
were presented as a natural part of the Czechoslovak society's life. There was no mention whatsoever of where they had come from, what they were doing here, not to speak of why they had come in the first place. Actually, it was not even mentioned that they were wives and children of Soviet officers. As a matter of fact, the circumstances of their arrival became separated from the Soviet soldiers themselves fairly soon. The year 1968 quickly disappeared from the list of great historical moments the Soviet Army was associated with, and only the struggle against Fascism and the liberation of Czechoslovakia in 1945 remained on it. With units of the Soviet Army present in Czechoslovakia, however, their celebrations acquired a new dimension. The impressive memorial which the Soviet Army had built in 1971 at its headquarters in Milovice was dedicated to the Czechoslovak-Soviet 'combat druzhba' arising from the Second World War. Through the "eternal symbol of friendship," the Soviet Army Command was conveying a message about the "tenacious struggle of soldiers of the Red Army against Fascism" and about the Soviet soldiers "sacrificing their lives so that we could live" to many visitors of the place. ${ }^{6}$ Stationed in Czechoslovakia since 1968, Soviet soldiers promoted their heroic war ancestors and presented themselves as their direct successors, or sons and grandsons, so much that they were sometimes mistaken for them. On the occasion of the 30th anniversary of the liberation of Czechoslovakia by the Red Army, several dozen officers from the local Soviet garrison were decorated in Olomouc: "The City Council of Olomouc has decided to award commemorative medals, honorable mentions, and commemorative sheets to Soviet officers as a token of the gratitude of our citizens for the liberation." "It should be noted that, save for one colonel who had allegedly "marched all the way to Berlin," none of them probably participated in the liberation of Czechoslovakia.

OBLIVION AND RELABELLING

Mentions of the modern time mission of the Soviet Army as interpreted in the Lesson from the Crisis Development in the early

6. Laník, L. "Věčný symbol přátelství." Nymbursko, May 13th, 1975.

7. "Vyznamenání sovětským důstojníkům." Stráž lidu, May 15th, 1975. 
1970s-i.e. as internationalist assistance against counterrevolution in 1968-practically disappeared from the public sphere, the only exceptions being the 10th and 20th anniversaries with more or less explicit references to August 1968, but even these were not any breakthrough of the controlled silence. If an official meaning or reason of the presence of the Soviet Army had to be given, it was relabelled. The saviours from the threat of counterrevolution became defenders of peace. The Soviet Army had gradually turned into a power "ensuring the peaceful upbuilding and development of socialism in our motherland. The Soviet Army is now a strong bulwark of peace against imperialist forces." 8 This motif was growing stronger since early 1980 , with an increasing accent on the arms race between the East and the West. In his article for local press, an editor of the Soviet newspaper published by the Soviet Army in Czechoslovakia characterized the mission of Soviet soldiers as follows:

Aggressive imperialist forces led by the United States are stepping up their feverish armament efforts, preparing a dreadful disaster for nations of the whole world. [...] there is not a goal more important than saving peace for people of the whole planet. Soviet armed forces are playing an important role in these peace efforts-as a mighty opponent of the aggressors grouped in the NATO. ${ }^{9}$

In due course, the 'internationalist help' to combat counterrevolution in 1968 changed into the 'internationalist mission'

1968 Transnational Legacies of the Soviet Army which-just like anywhere else in the worldposed as a defender of peace and socialism.

\section{LESSON FROM THE CRISIS DEVELOPMENT FOR A SECOND TIME}

Insofar as the memory of August 1968 during the Communist regime is concerned, we can observe a strange situation. Not only that the official memory and real life experience often diverge, particularly in totalitarian societies. There also were fundamental internal controversies in the official memory, especially at the level of proclamations and practical measures. In spite

8. Šindler, Jaroslav. "Den Sovětské armády a námořních sil." Krkonošská Pravda, February 23rd, 1978.

9. Isakov, Jevgenij. “Čtenářům Nymburska.” Nymbursko, May 26th, 1983. 
of the massively distributed Lesson from the Crisis Development which labelled the Prague Spring as an attempt at counterrevolution and the August invasion as friendly assistance, we can mainly see efforts to forget the whole year 1968 and, in particular, August 21st, 1968. The concept of the friendly help in the fight against counterrevolution was not supported by additional means of propaganda. The Lesson was thus floating in an ideological vacuum. Since 1972, there were no regular manifestations, commemorative events, lectures, films, memorial places, praised heroes or victims, no special programmes that would remind children of such events since their earliest childhood, as was the case of significant milestones of the Communist history (Zavacká 2013: 302-318). For those born after 1968 or too young at that time, the 'counterrevolution' or 'friendly assistance' were definitely not a subject of common ideological socialization. If they were ever presented the official version about the threat of counterrevolution bordering on a fratricidal struggle during their school years, which had to be suppressed by Soviet tanks, they were confused. As a matter of fact, the information was not connected with anything they knew, and thus remained incomprehensibly bizarre. Even an experience with the presence of Soviet troops, if any, did not help. As mentioned above, Soviet soldiers were not related to their arrival in 1968 roughly since the mid-1970s in the public sphere. For many younger people, Soviet soldiers were a natural part of their life, and they did not give much thought to where or why the latter had come from. A contemporary witness who had lived in a small town with a Soviet garrison until the age of sixteen recalled how her teachers had been asking her about it after her arrival to Prague. "I didn't know what they were talking about. I did not know that we had been occupied. [...] I did not know why the garrison was there or that something was wrong about it." (Vaněk, Urbášek 2005: 491) Others invented their own childish theories about the presence of Soviet soldiers. As a little boy, one of my respondents believed that Soviet soldiers had been in Czechoslovakia since the end of the war, which seemed logical to him, given the continuous reminder of the Soviet contribution to Czechoslovakia's liberation. Another one came up with a theory of reciprocity and was 
convinced that Soviet soldiers were in Czechoslovakia in exchange for Czechoslovak soldiers in the Soviet Union. Recollections like this illustrate the vagueness and fog which the year 1968 and the arrival of Soviet troops were veiled in, and also the level of ideological resignation of the regime toward this period. In many other respects, children were subject to propaganda since early childhood, and they were, first and foremost, guided to admire the Soviet Union, which effort was sometimes downright comical. A contemporary witness recalls how he and his father were watching a hockey game between Czechoslovakia and the Soviet Union sometime in the 1970s and how he asked his father which side he was supporting. "The school made me so stupefied that I was telling myself, why, if the glorious Red Army had liberated us, he might be a fan of the Soviet team because of gratitude. Dad just looked at me in amazement." (Otáhal, Vaněk 1999: 318). On the other hand, the year 1968 remained a mystery to many, a mystery which the regime explained in just one booklet that many students at that time ultimately did not even bother to read.

\section{MEMORY OF THE OCCUPATION}

The memory of the occupation was banished from the public to the private sphere, underground, or exile. Under the circumstances, it did not have ideal conditions for its cultivation, as it could not be openly communicated. Just like other alternative truths about the regime, it became a subject of more or less conscious

1968 Transnational Legacies family tactics among which silence was definitely not unusual. As a matter of fact, it was an approach proved on other sensitive issues, an approach which prevented children from being exposed to information a private interpretation of which might be different from the official one. Contrary to the official interpretation, however, the story about the violent occupation which ended the promising reform process often found support in the form of strong emotional ties in the family environment. In many households, the year 1968 was kept alive through fates of family members or friends whose professional careers were disrupted by the onset of the normalization process. Sanctions such as ousting from the Communist Party of Czechoslovakia or loss of employment due to 'wrong' attitudes during the 'period of crisis' of the Prague Spring and the invasion 
were difficult to conceal in families. If not for anything else, then because they had an adverse impact on the political evaluation of the 'culprits,' but also of their children. Access to the year 1968 was also possible through newspapers, magazines and books of that period, which people often kept at home, frequently hidden in closets, attics, cellars, or weekend cottages. It was exactly the search for and reading of these documents that were often an important moment of initiation for many people:

I always kept combing attics for old issues of the Reportér magazine [...] or I dug out an old issue of Literárky ${ }^{10}$ in our weekend cottage, I read all these things, and I sort of lived in a virtual world. (Otáhal, Vaněk 1999: 622)

In this respect, it was important that the information discovered in the manner described above or passed over by the closest relatives was perceived as a subversive element discrediting the regime. In the eyes of contemporaries, it was a conveyance of truth, which was in sharp contrast to the ideological lie of the regime, and also the regime's accusation.

At home, I was certainly influenced by my father who had been engaged in events of the Prague Spring. He told me the truth about the events of the Prague Spring; [...] he told me about things that we had not been told about during history lessons at school, he was giving me books that we didn't learn about. He simply gave me a true account of it. (Otáhal, Vaněk 2005: 549)

The communication or discovering of the hidden truth took on diverse forms; in the case of one of my respondents, it was almost a controlled family rite of initiation, associated with reaching the teen years and scheduled to take place on the tenth birthday.

My father told me: Well, you are ten now, so I have to explain some things to you [...] We spent the whole weekend together, with my father telling me about the Communist coup, how Communists imprisoned and murdered a lot of innocent people here [...] and that their regime is criminal and that we were occupied by the Soviets in 1968 and how it looked, how they invaded us...

10. The Reportér magazine and the Literárni noviny weekly, nicknamed Literárky, were extremely popular during the Prague Spring, they were labelled a bullhorn of counterrevolution in 1969 and subsequently disbanded. 
The testimony about the occupation, hidden in closets and attics, conveyed under special arrangements in families, or conspiratorially shared between closest friends had a hallmark of genuineness, sharply contrasting with the mock-up reality of the normalization regime. The awareness of this contrast led to a critical dissociation with its manifestations. Only when his parents had explained "how things really were" to him did my respondent start seeing the Soviet soldiers in his hometown, until then accepted as a normal part of life, as invaders. The forbidden knowledge about August 1968, its maintainence and sharing among exiles or dissenters, or in some family circles or with friends carried the potential of an anti-regime alliance. It is certainly not accidental that the date of August 21 was an important date of anti-regime protests in 1988 and 1989. It is true that it was the anniversary of the 'occupation,' but the principal reason of the demonstrations was the Communist regime rather than the Soviet Army presence.

\section{CONCLUSION}

The normalization regime turned the constitutive story about the hopes of the Prague Spring and the violent invasion that had ended it upside down. The real life experience of millions of people notwithstanding, it bulldozed through an official version about counterrevolution and the friendly assistance of allied armies of the Warsaw Pact. In spite of the initial loud hailing of August 21 as the date of victory over counterrevolution, the date started

1968 Transnational Legacies falling into oblivion. It is not that the regime abandoned its official interpretation of events; rather it stopped maintaining it ideologically. Reasons of the presence of the Soviet Army in Czechoslovakia were becoming vague and fuzzy. The Treaty on the Temporary Presence of Soviet Forces in Czechoslovakia postponed the departure of the Soviet troops indefinitely. The official silence ultimately fogged the circumstances of and reasons for their arrival. The Soviet Army inhabited the normalization presence as its natural component, without any clear beginning or end. The story about the occupation, which a large group of people in Czechoslovakia had shared in 1968, was banished from the public sphere and was, in a way, preserved in the hideouts of households, among exiles and dissenters, but also in the fates of numerous 
people. Regardless of what picture of the year 1968 it provided, it was in sharp contrast with the official interpretation, or rather non-interpretation. Although the manipulation with and forcing out of a certain memory after 1968 seemed to offer no hopes to the normalized society, the cornered truth obviously had enough energy to survive. On the contrary-it played an important role in the mobilization of the anti-regime protests in the end of the 1980s, which symptomatically took place on August 21.

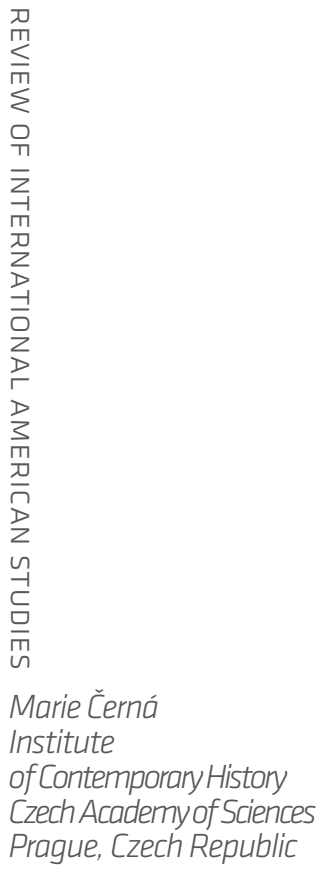


WORKS CITED

Černá, Marie. "Comprendre le processus de consolidation. Les campagnes de vérification de 1970 en Tchécoslovaquie." Cahier du CEFRES, 32, 2012, pp. 199-233.

Hoppe, Jiří (ed.). Pražské jaro v médiích: Výběr z dobové publicistiky. Doplněk, 2004, 16-17.

Hoppe, Jiři. Opozice '68: sociálni demokracie, KAN a K231 v období Pražského jara. Prostor, 2009.

Navrátil, Jaromír, ed. "The Moscow Protocol, August 26, 1968." The Prague Spring 1968: A National Security Archive Documents Reader. Central European UP, 1998, p. 477.

Navrátil, Jaromír, ed. "Bilateral Treaty on the 'Temporary Presence of Soviet Forces on Czechoslovak Territory,' October 16th, 1968. The Prague Spring 1968: A National Security Archive Documents Reader. Central European UP, 1998, pp. 533-536.

Otáhal, Milan, and Miroslav Vaněk, eds. „Rozhovor s Daliborem Fenclem." [Interview with Dalibor Fencl]. Sto studentských revolucí. Studenti v obdobi pádu komunismu-životopisná vyprávěni. Lidové noviny, 1999, pp. 317-328.

------. "Rozhovor s Janem Malurou." [Interview with Jan Malura] Sto studentských revoluci. Studenti v obdobi pádu komunismuživotopisná vyprávění. Lidové noviny, 1999, pp. 549-555.

------. "Rozhovor s Monikou Pajerovou." [Interview with Monika Pajerová] Sto studentských revoluci. Studenti v obdobi pádu

1968 Transnational Legacies komunismu-životopisná vyprávěni. Lidové noviny, 1999, pp. 621-636.

Slouka, Tomáš, ed. Poučeni z krizového vývoje ve straně a společnosti po XIII. Sjezdu KSČ. Státní pedagogické nakladatelství, 1972.

Vaněk, Miroslav, and Pavel Urbášek, eds. "Rozhovor s Hanou Marvanovou." [Interview with Hana Marvanová] Vitězové? Poražení? Životopisná interview. 1. dil. Disent v období normalizace. Prostor, 2005, pp. 489-509.

Vondrová, Jitka. "Memorandum k některým zásadním otázkám vnitropolitické situcace ČSSR a sovětsko-československých vztahů, předložené sovětským velvyslancem v Československu S.V. Červoněnkem, 10-17. července 1969." Prameny k dějinám československé krize v letech 1967-1970, 4/4. Mezinárodni sou- 
vislosti československé krize 1967-1970. Dokumenty ÚV KSSS 1966-1969. Doplněk, 2011, 459-478.

Vondrová, Jitka, and Jaromír Navrátil. "Sovětský záznam z jednání předsedy vlády ČSSR O. Černíka a místopredsedy vlády ČSSR F. Hamouze s L. Brežněvem, A. Kosyginem a N. Podgornym v Kremlu o aktuálních otázkách československé vnitropolitické situace z hlediska plnění moskevských dohod, 10. zárí, 1968." Prameny k dějinám československé krize v letech 1967-1970, 4/3. Mezinárodni souvislosti československé krize 1967-1970 (záŕr 1968-květen 1970). Doplněk, 1997, pp. 35-47.

-----_. “Usnesení prijijaté na zasedání ústředního výboru KSČ, 26. zárii 1969." Prameny k dějinám československé krize v letech 19671970, 9/4. Komunistická strana Československa: Normalizace (listopad 1968-zárí 1969. Doplněk, 2003, p. 599.

Vondrová, Jitka, and Jaromír Navrátil, eds. "Prohlášení predsednictva ústředního výboru KSČ k obsazení Československa vojsky pěti států Varšavské smlouvy, 21. srpna 1968." Prameny k dějinám československé krize v letech 1967-1970, 9/2. Komunistická strana Československa: Konsolidace (květen-srpen 1968). Doplněk, 2000, p. 454.

------. "Stenografický záznam ze zasedání ústředního výboru KSČ 31. srpna k závěrům moskevského jednání." Prameny k dějinám československé krize v letech 1967-1970, 9/3. Komunistická strana Československa: Kapitulace (srpen-listopad 1968). Doplněk, 2001, p. 213-261.

Zavacká, Marína. "Propagandistická rezignácia: rok 1968 a jeho režimový výklad pre mládež." Odvalujem balvan: pocta historickému remeslu Jozefa Jablonického, edited by Kmet' Norbert, and Syrný Marek et al., Múzeum Slovenského národného povstania, 2013, pp. 302-318.
Marie Černá Institute of Contemporary History Czech Academy of Sciences Prague, Czech Republic 
